\title{
Fine mapping of the 9q31 Hirschsprung's disease locus
}

\author{
C. S. Tang $\cdot$ Y. Sribudiani $\cdot$ X. P. Miao $\cdot$ A. R. de Vries $\cdot$ G. Burzynski $\cdot$ \\ M. T. So $\cdot$ Y. Y. Leon - B. H. Yip · J. Osinga $\cdot$ K. J. W. S. Hui • J. B. G. M. Verheij • \\ S. S. Cherny • P. K. H. Tam • P. C. Sham • R. M. W. Hofstra • M. M. Garcia-Barceló
}

Received: 11 February 2010/Accepted: 17 March 2010/Published online: 2 April 2010

(c) The Author(s) 2010. This article is published with open access at Springerlink.com

\begin{abstract}
Hirschsprung's disease (HSCR) is a congenital disorder characterised by the absence of ganglia along variable lengths of the intestine. The RET gene is the major HSCR gene. Reduced penetrance of RET mutations and phenotypic variability suggest the involvement of additional modifying genes in the disease. A RET-dependent modifier locus was mapped to $9 \mathrm{q} 31$ in families bearing no coding sequence (CDS) RET mutations. Yet, the 9q31 causative locus is to be identified. To fine-map the $9 \mathrm{q} 31$ region, we genotyped 301 tag-SNPs spanning $7 \mathrm{Mb}$ on 137 HSCR Dutch trios. This revealed two HSCR-associated regions that were further investigated in 173 Chinese HSCR patients and 436 controls using the genotype data obtained from a genome-wide association study recently
\end{abstract}

C. S. Tang and Y. Sribudiani contributed equally to this work.

Electronic supplementary material The online version of this article (doi:10.1007/s00439-010-0813-8) contains supplementary material, which is available to authorized users.

C. S. Tang - B. H. Yip - S. S. Cherny · P. C. Sham

Department of Psychiatry, The University of Hong Kong,

Hong Kong, China

X. P. Miao - M. T. So - Y. Y. Leon - B. H. Yip .

K. J. W. S. Hui · P. K. H. Tam - M. M. Garcia-Barceló

Department of Surgery, The University of Hong Kong,

Hong Kong, China

P. C. Sham

Genome Research Centre, The University of Hong Kong,

Hong Kong, China

P. K. H. Tam · P. C. Sham · M. M. Garcia-Barceló $(\bowtie)$

Centre for Reproduction, Development, and Growth,

The University of Hong Kong, Hong Kong, China

e-mail: mmgarcia@hku.hk conducted. Within one of the two identified regions SVEP1 SNPs were found associated with Dutch HSCR patients in the absence of RET mutations. This ratifies the reported linkage to the 9q31 region in HSCR families with no RET CDS mutations. However, this finding could not be replicated. In Chinese, HSCR was found associated with $I K B$ $K A P$. In contrast, this association was stronger in patients carrying RET CDS mutations with $p=5.10 \times 10^{-6}$ $[\mathrm{OR}=3.32(1.99,5.59)]$ after replication. The HSCRassociation found for IKBKAP in Chinese suggests population specificity and implies that $R E T$ mutation carriers may have an additional risk. Our finding is supported by the role of IKBKAP in the development of the nervous system.

\section{Introduction}

Hirschsprung's disease (HSCR; aganglionic megacolon) is a congenital disorder characterised by the absence of enteric ganglia along a variable length of hindgut. There is

\footnotetext{
Y. Sribudiani - A. R. de Vries · G. Burzynski - J. Osinga ·

J. B. G. M. Verheij · R. M. W. Hofstra ( $\square)$

Department of Genetics, University Medical Center Groningen,

University of Groningen, Groningen, The Netherlands

e-mail: r.m.w.hofstra@medgen.umcg.nl

G. Burzynski

McKusick-Nathans Institute of Genetic Medicine,

Johns Hopkins University School of Medicine,

Baltimore, MD, USA

X. P. Miao

Department of Epidemiology and Biostatistics,

School of Public Health, Tongji Medical College,

Huazhong University of Science and Technology, Wuhan, China
} 
significant ethnic variation in the incidence of the disease, and it is most often found among Asians (2.8 per 10,000 live births; Amiel and Lyonnet 2001; Torfs 1998). Nonfamilial HSCR has a complex pattern of inheritance and manifests with low, sex-dependent penetrance and variability in the length of the aganglionic segment, according to which patients are classified into short segment (SHSCR; 80\%), long segment (L-HSCR; 15\%), and total colonic aganglionosis (TCA 5\%). The male:female ratio $(\mathrm{M}: \mathrm{F})$ is $\approx 4: 1$ among S-HSCR patients and $\approx 1: 1$ among L-HSCR patients. HSCR presents mostly sporadically although it can be familial (5-20\% of cases), where the recurrence risks to sibs vary from 1.5 to $33 \%$ depending on the gender and the length of the aganglionic segment in the proband, and the gender of the sibling (Badner et al. 1990).

The RET gene, encoding a tyrosine-kinase receptor, is the major HSCR causing gene (Edery et al. 1994; Romeo et al. 1994) and its expression is crucial for the development of the enteric ganglia. Mutations in the coding sequence (CDS) of RET account for up to $50 \%$ of the familial cases and between 15 and $20 \%$ of the sporadic cases indicating that additional HSCR-causing mutations exist (Hofstra et al. 2000). Other HSCR genes identified so far mainly code for protein members of interrelated signalling pathways involved in the development of enteric ganglia: RET, endothelin receptor B (EDNRB), and the transcriptional regulator SOX10. Yet, mutations in genes other than RET (GDNF, GFRA1, NRTN, PHOX2B, NKX2.1, SOX10, NRG1, EDNRB, EDN3, ECE-1, KIAA1279, ZFXH1B, NTRK3, and LICAM) account for only 7\% (Amiel et al. 2003; Angrist et al. 1996; Brooks et al. 2005; Fernandez et al. 2009; Hofstra et al. 1996, 1999; Pingault et al. 1998; Puffenberger et al. 1994; Wakamatsu et al. 2001). Failure to identify RET CDS mutations in some of the RET-linked families suggests that noncoding $R E T$ mutations, mutations in regulatory regions of RET could also contribute significantly to the disease. Indeed, common RET single nucleotide polymorphisms (SNPs) are strongly associated with HSCR, with the largest contribution to risk made by a functional SNP (rs2435357) lying in an enhancer-like sequence in intron 1 (Burzynski et al. 2004, 2005; Fernandez et al. 2005; Fitze et al. 2002, 2003a, b; Garcia-Barcelo et al. 2003, 2005; Sancandi et al. 2003). We have recently reported the genetic interaction of RET intron 1 SNP (rs2435357) with HSCR-associated $N R G 1$ SNPs, whereby the risk to HSCR is increased by 2.3-fold for the RET risk genotype (Garcia-Barcelo et al. 2009).

Reduced penetrance of RET and other HSCR gene mutations and variable expression of the HSCR phenotype indicate that the disease may result from the combined effect of several genes, whereby the outcome would be altered RET expression (Cantrell et al. 2004; Carrasquillo et al. 2002; Lang et al. 2000; Lang and Epstein 2003; McCallion et al. 2003).

RET modifiers have been mapped to the following chromosomal regions: (i) 3p21; (ii) 19q12 (Gabriel et al. 2002); (iii) 4q31.3-q32.3 (Brooks et al. 2006), and (iv) $9 \mathrm{q} 31$. Despite these important findings, the genes in these loci are yet to be identified. The $9 \mathrm{q} 31$ locus segregated in families of European descent harbouring no or hypomorphic RET mutations, yet the families still showed linkage to 10q12 (RET locus) (Bolk et al. 2000b).

To identify the HSCR locus in the $9 \mathrm{q} 31$ candidate region, we have conducted dense genotyping of the region of a Dutch patient cohort and evaluated the same region in Chinese.

\section{Materials and methods}

The overall study was approved by the institutional review board of The University of Hong Kong together with the Hospital Authority (IRB: UW 07-292).

\section{Dutch (Groningen) family-based association study}

The Dutch patient cohort consisted of 140 HSCR trios that were genotyped using Illumina GoldenGate platform for 370 SNPs spanning the $7 \mathrm{Mb}$ (from 108.5 to $115.5 \mathrm{Mb}$ ) of the 9q31 HSCR-associated region as described by Bolk et al. Most of these 370 SNPs were tag SNPs. Quality control based on identity-by-descent (IBD) revealed 3 duplicated trios. SNPs with missing genotypes $(>5 \%)$ and with minor allele frequency (MAF) $<5 \%$, and/or violating Hardy-Weinberg equilibrium $(p<0.001)$ were excluded, leaving a total of 301 SNPs for association study. PLINK (Purcell et al. 2007) was then used to conduct the TDT analysis in the resulting 137 Dutch trios. As much as 16 HSCR probands carried RET CDS mutations.

Chinese case-control analysis

\section{Subjects}

For analysis of the $9 \mathrm{q} 31$ region in the Chinese sample, we revised the genotype data of the candidate $9 \mathrm{q} 31.3$ region obtained from a previous genome-wide association study (GWAS) conducted on a total of 181 HSCR Chinese patients and 386 healthy individuals (discovery group) using Affymetrix GeneChip ${ }^{\circledR}$ Human Mapping 500K Array as previously described (Garcia-Barcelo et al. 2009). To that data, we included 92 additional controls recently genotyped (see below).

For the replication of the association found when patients were stratified according to the RET mutation 
status, we included 21 independent HSCR cases bearing RET CDS mutations and 71 control individuals from Mainland China (replication group).

Characteristics of the patients are depicted in supplementary Tables 1 and 2 .

\section{Revision of the Affymetrix 500K data}

Following the recent recommendations on quality control standards (Sklar et al. 2008), we imposed a more stringent filtering criterion based on heterozygosity to the GWAS described above. Heterozygosity screening aims at the identification of individuals who have more heterozygous genotype calls than the average of the sample set, since the excess of heterozygosity is likely due to cross-contamination of samples. Hence, outliers should be excluded from the analysis. Prior to evaluating the heterozygosity of the samples, we pruned the SNP dataset to avoid bias that could have been introduced by large quantities of SNPs in strong LD. In brief, we pruned the dataset (by removing 1 of a pair of SNPs with $r^{2}>0.25$ within a window of 200 SNPs and shifts of 50 SNPs forward at each step) using PLINK. In total, 56,000 SNPs in weak LD with each other remained. The heterozygosity screening excluded outliers with more heterozygous calls than the average (estimated inbreeding coefficient lower than 3 standard deviations from the average).

After this filtering criteria, a total of 173 HSCR cases (31 patients bearing RET CDS mutations) and 436 controls were included in the analysis. Restricting by the region analysed by the Dutch group, 988 SNPs falling within the $9 \mathrm{q} 317 \mathrm{Mb}$ candidate region (from 108.5 to $115.5 \mathrm{Mb}$ ) were selected. The mean call rate was $99.09 \%$. After filtering by MAF, genotyping rate and Hardy-Weinberg equilibrium, 981 SNPs were left for analysis.

\section{Correction for population structure and association analysis}

We used the EIGENSOFT package on the whole genome data pruned for LD as described above to detect population substructure. The Tracy-Widom test (implemented in EIGENSOFT) nominated only the first two axes of variation as significant $(p<0.05)$. The first axis of variation corresponded to the ancestral differences between Northern and Southern Chinese as seen in supplementary Fig. 1. To correct for these ancestral differences, we applied EIGENSTRAT (Price et al. 2006) (also implemented in EIGENSOFT) on the candidate regions based on the two axes of variation nominated by the Tracy-Widom test. The Cochran-Armitage trend test was then used to assess the levels of association of the SNPs with HSCR.
Replication stage

EIGENSTRAT could not be applied to correct the replication sample for population stratification as no genealogy information can be inferred when only two SNPs are genotyped. Logistic regression was carried out instead to assess the association in the combined sample (discovery + replication samples). We included a covariate for the sample ancestral origin (northern and southern Chinese ancestry) and a covariate to distinguish GWAS and replication samples, thereby controlling for any possible allele frequency differences between known populations and between stages of association analysis. We also tested the interaction terms between each covariate and the genotype, which were not found to be significant $(p>0.5$ for both, indicating that the effect is not significantly different between subpopulations or stages). Thus, only the two covariates were included in the final model for combined analysis.

\section{Results}

Family-based association test on Dutch trios identifies two associated regions on $9 \mathrm{q} 31$

Through TDT analysis of 301 SNPs on 137 Dutch trios, we identified 17 SNPs (supplementary Table 3) $(p<0.05)$ showing asymmetrical transmission from parents. Of these, 10 SNPs could be grouped into 2 moderately associated peaks of 5 SNPs each, 9q31A $(110.7-111.1 \mathrm{Mb})$ and B (112.1-112.7 Mb).

The 9q31A region encompasses a gene-rich spot which contains 4 genes IKBKAP, C9orf6, CTNNAL1, and C9orf5 within a single LD block that spans about $100 \mathrm{~kb}$. Among the 5 associated SNPs, the strongest evidence for association with HSCR was found for $\operatorname{rs} 12351693(p=0.023)$ and $\operatorname{rs} 10979637(p=0.023)$ located within the intronic region of CTNNAL1 (Table 1; Fig. 1a).

CTNNAL1 encodes alpha-catulin, a protein that modulates the Rho signalling pathway by providing a scaffold for the ARHGEF1 (Park et al. 2002). The expression of its mouse homologue, Ctnnall, was found to be severely reduced in intestines of Ret deficient mice $\left(R e t^{k-k-}\right)$ when compared to normal mice $\left(\operatorname{Ret}^{+/+}\right)$and consequently, the gene has been considered a putative RET modifier (Heanue and Pachnis 2006).

However, the strongest associations lied in $9 \mathrm{q} 31 \mathrm{~B}$ and mapped upstream the TXNDC8 gene $\left(p=4.8 \times 10^{-3}\right.$ for rs7038415), and in the intronic region of SVEP1 $\left(p=2.9 \times 10^{-3}\right.$ for $\left.\mathrm{rs} 10816998\right) \quad$ (Table 1). Other associated SNPs within the 9q31B region, mapped to the MUSK gene. MUSK is required for neuromuscular 
Table $19 \mathrm{q} 31 \mathrm{~A}$ and B SNPs associated with HSCR in Dutch trios samples

\begin{tabular}{|c|c|c|c|c|c|c|}
\hline & \multirow[t]{2}{*}{ Position (bp) } & \multicolumn{2}{|c|}{ Allele } & \multirow[t]{2}{*}{ Overlapping gene } & \multirow[t]{2}{*}{ Location } & \multirow[t]{2}{*}{$p$ value $^{\mathrm{a}}$} \\
\hline & & A & $\mathrm{B}$ & & & \\
\hline \multicolumn{7}{|l|}{$9 \mathrm{q} 31 \mathrm{~A}$} \\
\hline rs 12351693 & 110751336 & $\mathrm{G}$ & A & CTNNAL1 & Intron 13 & 0.023 \\
\hline rs10979637 & 110784448 & $\mathrm{C}$ & A & CTNNAL1 & Intron 6 & 0.023 \\
\hline rs 12555920 & 110805558 & $\mathrm{~T}$ & $\mathrm{C}$ & CTNNAL1 & Intron 1 & 0.041 \\
\hline rs 1333344 & 110816045 & A & G & $\begin{array}{l}\text { CTNNAL1 } \\
\text { C9orf5 }\end{array}$ & $\begin{array}{l}\text { Downstream } \\
\text { upstream }\end{array}$ & 0.046 \\
\hline rs 1044905 & 110821316 & $\mathrm{~T}$ & $\mathrm{C}$ & C9orf5 & $3^{\prime}$ UTR & 0.028 \\
\hline \multicolumn{7}{|l|}{$9 \mathrm{q} 31 \mathrm{~B}$} \\
\hline rs7038415 & 112157004 & A & $\mathrm{C}$ & $\begin{array}{l}\text { TXNDC8 } \\
\text { SVEP1 }\end{array}$ & $\begin{array}{l}\text { Upstream } \\
\text { Downstream }\end{array}$ & 0.0048 \\
\hline rs10816998 & 112173562 & G & A & SVEP1 & Intron 46 & 0.0029 \\
\hline rs3010815 & 112473999 & $\mathrm{~T}$ & $\mathrm{C}$ & MUSK & Intron 1 & 0.046 \\
\hline rs2766998 & 112571406 & $\mathrm{~T}$ & $\mathrm{C}$ & MUSK & Intron 9 & 0.029 \\
\hline rs3780529 & 112601072 & $\mathrm{C}$ & A & MUSK & Intron 14 & 0.035 \\
\hline
\end{tabular}

${ }^{a} p$ value for the transmission disequilibrium test (TDT)
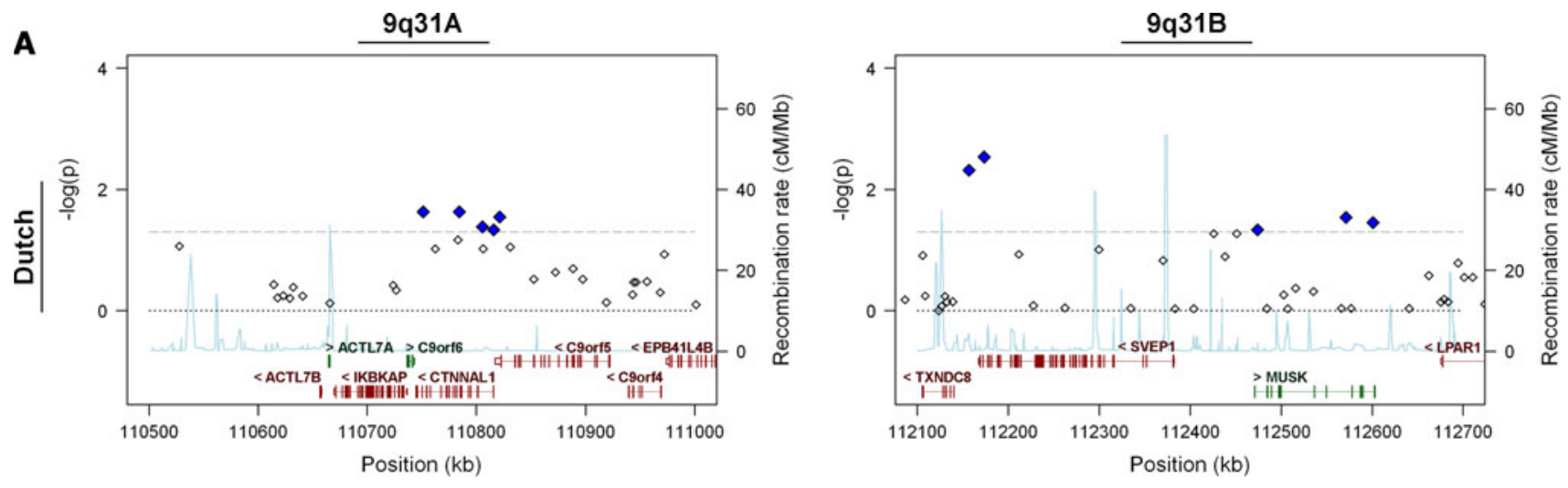

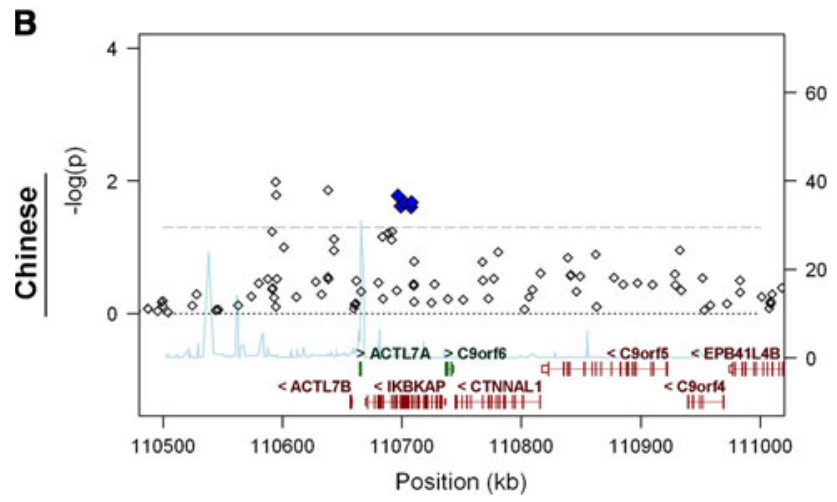

Fig. 1 Association analysis on 9q31A (110,500-111,000 kb) (left panel) and 9q31B (112,000-112,500 kb) (right panel). a TDT analysis on 137 Dutch HSCR trios and b Case-control study on

junction formation in vivo and for the survival and development of discrete neuronal subpopulations (Kiba et al. 2009). The associations described above were confirmed by performing 1 million permutations (Table 1; Fig. 1).

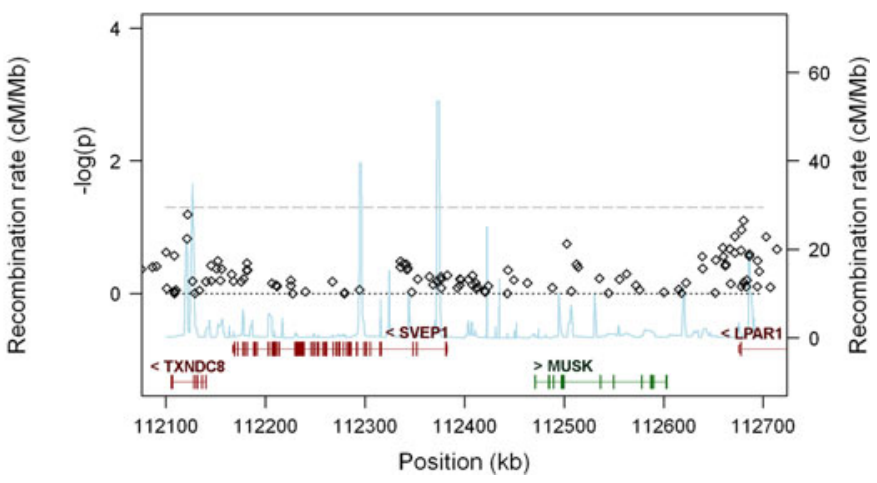

Chinese using $500 \mathrm{k}$. Associated SNPs listed in Tables 1 and 2 are represented as blue diamonds. Recombination rate and genes in the region are also shown (green "+" strand; red "-" strand)

SVEP1 is associated with HSCR in Dutch patients without RET mutations

As it was reported that the $9 \mathrm{q} 31$ HSCR susceptibility locus segregated exclusively in RET-linked families depleted of 
RET CDS mutations (Bolk et al. 2000b), we stratified the cases according to their RET CDS mutation status. We defined RET CDS mutations as DNA changes in the coding region or exon/intron boundaries of RET that lead to frameshift, non-sense or missense mutations in the RET protein and that have not been found in at least 400 control chromosomes. PolyPhen (Sunyaev et al. 2001) was used to predict the effect of the missense mutations on the RET protein. Truncating mutations were considered highly deleterious.

The 301 SNPs in the 9q31 region were checked again for association. The rs10816998 and rs7038415 SNPs within SVEP1 were strongly associated with HSCR in families without RET mutations. After stratification of the patients, the OR attained a significance level of $p=5.33 \times 10^{-5}$ with OR $=2.379(95 \% \mathrm{CI}: 1.542,3.671)$ for $\mathrm{rs} 10816998$ and $p=7.50 \times 10^{-5}$ with $\mathrm{OR}=2.345$ (95\% CI:1.518, 3.622) for rs7038415. These association values survived the conservative Bonferroni correction for multiple testing ( $\approx 300$ SNPs). This finding in the Dutch population is in line with the reported linkage of $9 q 31$ with HSCR in patients of European descent bearing no or hypomorphic RET mutations (Bolk et al. 2000a).

The SVEP1 SNPs, rs10816998 and rs7038415, were then genotyped in 107 independent Dutch patients without RET CDS mutations and 183 controls. Unfortunately, the $p$ value of the replication did not reach statistical significance.

Revision of the population-based GWAS on Chinese identifies IKBKAP as a HSCR candidate gene

We used the GWAS data (above described) to investigate the association observed in the Dutch. After EIGENSTRAT correction for stratification (see Sect. Materials and methods and supplementary material), genotypes of 981 SNPs spanning the entire 9q31 region were tested for association on $173 \mathrm{HSCR}$ patients (31 with RET CDS mutations) and 436 controls.

In the Chinese dataset, 6 SNPs within the 9q31A region showed association with HSCR. No association was found in 9q31B. The loci displaying the strongest statistical evidence for association were rs10979596 and rs10979597 (in intron 25 of the IKBKAP gene) which are in complete LD with each other $\left(r^{2}=1\right)$ (Fig. 1b; Table 2). Four additional SNPs within IKBKAP also showed marginally significant association $(p<0.03)$ with HSCR. These include the IKBKAP I816L missense polymorphism (rs2230793, $p=0.024$ ) and 3 intronic SNPs (Table 2). Mutations in $I K B K A P$ (inhibitor of kappa light polypeptide gene enhancer in B cells kinase complex-associated protein, involved in transcription elongation) are associated with a neurodevelopmental disease, the Riley-Day syndrome, also known as familial dysautonomia (FD) (Anderson et al. 2001; Slaugenhaupt et al. 2001). FD is an autosomal recessive disorder that occurs almost exclusively in persons of Ashkenazi Jewish descent. This neuropathy results from depletion of subsets of autonomic and sensory neurons (Slaugenhaupt and Gusella 2002). FD patients are born with fewer neurons in their dorsal root and sympathetic ganglia than their peers, and over time, neurons become more scarce (Mezey et al. 2003). Most importantly, some patients with FD also suffer from gastrointestinal dysfunction shortly after birth and interestingly, the cooccurrence of both FD and HSCR has been reported (Azizi et al. 1984). Interestingly, the region encompassing our 6 IKBKAP associated SNPs includes the region where FDcausing mutations lie. Ikbkap is expressed in the rat developing gut and IKBKAP in the human colon, supporting a biological role for this gene in the development of enteric nervous system (Bar-Shai et al. 2004; Mezey et al. 2003).

\section{The association of IKBKAP is stronger in Chinese HSCR} patients with RET mutations

The Chinese HSCR patients were also stratified according to the RET CDS mutation status. We then tested again the 981 SNPs in the $9 q 31$ region for association by independently comparing RET CDS mutation carriers (31 Chinese HSCR patients; discovery group) against 436 controls as well as non-carriers (142 HSCR patients) versus the same control set.

As much as 12 SNPs were found associated with HSCR in RET mutation carriers $(p<0.01)$. Importantly, 6 of these SNPs mapped to the IKBKAP loci in the $9 \mathrm{q} 31 \mathrm{~A}$ and had been found associated with HSCR before the stratification of the patients according to the mutation status (Fig. 2). This data suggested that the initial association detected was mainly driven by this subset of RET mutation carriers and that the original marginal association had been masked prior stratification because of the small number of carriers. Among the 12 SNPs segregating with RET mutations, 4 IKBKAP SNPs survived the conservative Bonferroni correction for multiple testing ( $\approx 1,000$ SNPs) (Table 3). The frequency of the risk SNP alleles tended to increase with the severity of the RET mutations, yet the small sample does not allow to draw any conclusion (Table 3).

To validate the association of the IKBKAP SNPs with HSCR patients carrying RET CDS mutations, we genotyped (by PCR followed by direct sequencing) the 2 perfectly linked SNPs (rs10979596 and rs10979597) in an independent set of $21 \mathrm{HSCR}$ patients (replication group) bearing RET mutations and 71 controls collected from mainland China. These SNPs were chosen for replication 
Table 2 9q31A SNPs associated with HSCR in Chinese

\begin{tabular}{|c|c|c|c|c|c|c|c|c|}
\hline & \multirow[t]{2}{*}{ Position (bp) } & \multicolumn{2}{|c|}{ Allele } & \multirow[t]{2}{*}{$I K B K A P$} & \multirow[t]{2}{*}{ OR $(95 \% \mathrm{CI})$} & \multicolumn{2}{|c|}{ Frequencies } & \multirow[t]{2}{*}{$p$ value $^{\mathrm{a}}$} \\
\hline & & A & $\mathrm{B}$ & & & Cases & Controls & \\
\hline \multicolumn{9}{|l|}{$9 \mathrm{q} 31 \mathrm{~A}$} \\
\hline rs10979596 & 110696824 & G & $\mathrm{T}$ & Intron 25 & $1.53(1.10,2.13)$ & 0.20 & 0.14 & 0.017 \\
\hline rs10979597 & 110696853 & A & $\mathrm{T}$ & Intron 25 & $1.53(1.10,2.13)$ & 0.20 & 0.14 & 0.017 \\
\hline rs2230793 & 110699304 & G & $\mathrm{T}$ & I816L exon 23 & $1.58(1.20,2.09)$ & 0.32 & 0.23 & 0.024 \\
\hline rs 2275630 & 110702228 & G & A & Intron 19 & $1.68(1.12,2.51)$ & 0.13 & 0.08 & 0.021 \\
\hline rs10979607 & 110707646 & G & A & Intron 14 & $1.49(1.08,2.06)$ & 0.20 & 0.14 & 0.025 \\
\hline rs4369056 & 110708259 & $\mathrm{~T}$ & $\mathrm{C}$ & Intron 14 & $1.58(1.21,2.08)$ & 0.33 & 0.24 & 0.021 \\
\hline
\end{tabular}

$A$ minor allele, $B$ major allele

${ }^{\text {a }}$ Corrected trend test computed using EIGENSTRAT

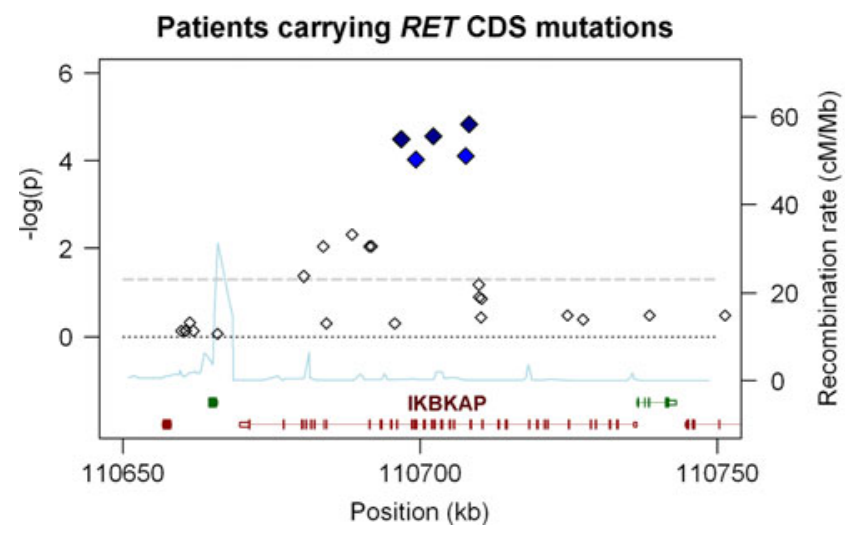

Fig. 2 Association analysis on RET Chinese CDS mutation carriers (left) and Chinese non-carriers (right). Blue diamonds represent associated SNPs before stratification by mutation status. Dark blue

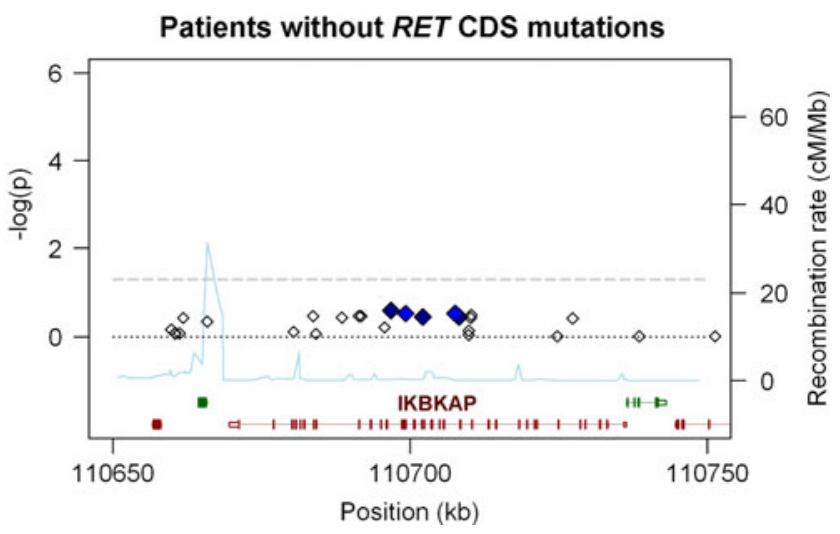

diamonds indicate the 4 SNPs that survived the Bonferroni correction multiple for testing (only 3 dark blue diamonds can be observed as there is overlapping between two SNPs)

Table 3 IKBKAP SNPs associated (survived Bonferroni correction for multiple testing) with HSCR patients with RET CDS mutations

\begin{tabular}{|c|c|c|c|c|c|c|c|c|}
\hline & \multirow[t]{2}{*}{ Risk allele } & \multicolumn{5}{|c|}{ MAF of risk allele } & \multirow[t]{2}{*}{ OR $(95 \% \mathrm{CI})$} & \multirow[t]{2}{*}{ Trend test $p$-value } \\
\hline & & $R E T^{\mathrm{a}}$ & Highly deleterious & Damaging & Tolerating & Controls & & \\
\hline rs4369056 & $\mathrm{T}$ & 0.52 & 0.75 & 0.50 & 0.47 & 0.24 & $3.44(2.04,5.80)$ & $1.48 \times 10^{-5}$ \\
\hline rs2275630 & $\mathrm{G}$ & 0.25 & 0.38 & 0.30 & 0.19 & 0.08 & $3.83(2.03,7.23)$ & $2.79 \times 10^{-5}$ \\
\hline rs $10979596^{\mathrm{b}}$ & G & 0.34 & 0.63 & 0.35 & 0.32 & 0.14 & $3.21(1.83,5.62)$ & $3.25 \times 10^{-5}$ \\
\hline rs10979597 ${ }^{\mathrm{b}}$ & A & & & & & & & \\
\hline
\end{tabular}

$M A F$ minor allele frequency; Note that the MAFs increase with the severity of the RET mutation

${ }^{a}$ Frequency in HSCR patients carrying RET CDS mutations

b Same frequencies for these two SNPs as $r^{2}=1$

c Corrected trend test computed using EIGENSTRAT

because they fall in the same amplicon and on the basis of genetic homogeneity between Northern and Southern Chinese. We successfully detected the association of rs10979596 and rs 10979597 in the replication sample, with logistic regression association value of $p=9.45 \times 10^{-3}$ and $\mathrm{OR}=3.38(95 \% \mathrm{CI}: 1.35,8.49)($ Table 4$)$. Logistic regression was also used for the combined analysis of HSCR samples bearing RET mutations (discovery-31 patients and replication-21 patients). This yielded a highly significant association of $p=2.71 \times 10^{-6}$ and $\mathrm{OR}=3.15$ (95\% CI: $1.95,5.09)$ for the heterozygous genotype under an additive model. Considering the 
Table 4 Summary of the statistics for the IKBKAP rs10979596 and rs10979597 markers in RET mutation carriers

\begin{tabular}{|c|c|c|c|c|c|c|c|c|}
\hline \multirow[t]{2}{*}{ Phase } & \multicolumn{2}{|l|}{$\mathrm{N}$} & \multicolumn{2}{|l|}{ MAF } & \multicolumn{4}{|l|}{ Logistic $^{a}$} \\
\hline & $R E T^{\mathrm{b}}$ & Controls & $R E T^{\mathrm{b}}$ & Controls & OR $(95 \% \mathrm{CI})$ & $p$ (adjusted) & OR $(95 \% \mathrm{CI})$ & $p$ (non-adjusted) \\
\hline $500 \mathrm{~K}$ & 31 & 436 & 0.34 & 0.14 & $3.31(1.77,6.18)$ & $1.78 \times 10^{-4}$ & $3.38(1.86,6.12)$ & $6.13 \times 10^{-5}$ \\
\hline Replication & 21 & 71 & 0.29 & 0.11 & NA & NA & $3.38(1.35,8.49)$ & $9.45 \times 10^{-3}$ \\
\hline Combined & 52 & 507 & 0.319 & 0.13 & $3.32(1.99,5.59)$ & $5.10 \times 10^{-6}$ & $3.15(1.95,5.09)$ & $2.71 \times 10^{-6}$ \\
\hline
\end{tabular}

$N A$ all cases and controls used in the replication stage had the same ancestral origin of northern Chinese

${ }^{a} P$ value adjusted for population substructure in GWAS (500K) analysis and for both the substructure and strata defining analysis stages (500K and replication) in combined analysis

${ }^{\mathrm{b}}$ HSCR patients carrying RET CDS mutations

possible population stratification, we employed the same logistic regression approach conditioning on the strata defined by sample origins (Northern and Southern Chinese), obtaining a significant level of association of $p=5.75 \times 10^{-6}$ with $\mathrm{OR}=3.29(95 \%$ CI: $1.97,5.51)$ (Table 4). Results of the latter approach were very similar, indicating that samples collected inside and outside Hong Kong (discovery and replication phases) were homogeneous, with little stratification.

\section{Discussion}

This study aims at the identification of a HSCR susceptibility locus in the $9 \mathrm{q} 31$ region. As the association of this region was initially reported in families of European descent, we first explored the region in a Dutch cohort. As the evaluation of an association in two populations of different ethnic origins would definitively increase confidence in the finding, we also explored the 9q31 region in the Chinese. We reasoned that this strategy would allow us to determine (i) whether the $9 \mathrm{q} 31$ locus exerted an effect in patients of European descent other than those in whom the locus was initially identified, (ii) assess whether the association of the $9 \mathrm{q} 31$ locus with HSCR is population specific, and if not (iii) use population differences in LD to fine-map the gene of interest.

Our data show an initial strong association of SVEP1 SNPs with Dutch HSCR patients bearing no RET CDS mutations. This finding ratifies the reported linkage to the 9q31 region in HSCR families with no RET CDS mutations. The case-control replication of the SVEP1 association in the Dutch did not reach statistical significance indicating that the initial association was spurious or that there is a population stratification issue in the samples used for replication. This point would need further exploration in a much larger sample. The role of SVEPI is not well characterised. Study of its possible implications in the development of the nervous system should follow.
Intriguingly, the analysis of the region in the Chinese population demonstrated the existence of a HSCR-associated locus $(I K B K A P)$ that, although within $9 \mathrm{q} 31$, is not correlated at all with the SVEPI locus identified in the Dutch. The association of IKBKAP SNPs with HSCR in Chinese became much more prominent in those patients with RET CDS mutations which is at odds with the initial findings described by Bolk and our own findings in the Dutch. Importantly, the IKBKAP association with HSCR bearing RET CDS mutations was replicated in the same Chinese population. No IKBKAP association was detected in the Dutch (supplementary Table 4).

We investigated whether the lack of cross-population replication of the associations of SVEPI and IKBKAP SNPs with HSCR could be due to population LD and allele frequencies differences, in which case, some true associations may not be replicated, regardless of the sample size of the study. Close examination of the SVEPI and IKBKAP regions showed no major LD differences between CEU and CHB HapMap populations indicating that lack of replication across populations was not due to differences in $\mathrm{LD}$ structure (supplementary Figs. 2 and 3). Lack of replication could also be attributed to a false positive result on the Chinese sample although we think this is unlikely since the initial association found in Chinese was replicated in an independent sample.

In view of these results, we would conclude that the 9q31 locus that appears associated with HSCR in families bearing no RET CDS mutations is indeed population specific, as the findings in Chinese point to a different locus with a completely different genetic behaviour than that identified in the Dutch. As 9q31 locus was reported to segregate exclusively with $R E T$-linked families of Caucasian origin whose members had weak or hypomorphic $R E T$ CDS mutations, the investigation of SVEPI rare variants in these types of patients is warranted.

The association of IKBKAP in Chinese implies that RET mutation carriers may have an additional risk. As yet, no genotype-phenotype correlation could be found which, 
after all, is in line with the genetic complexity inherent to HSCR. Had parental DNA been available, we might have been able to provide an argument for the role of IKBKAP SNPs on the penetrance of inherited RET CDS mutations. SNPs may modulate the penetrance or phenotype of a particular mutation through epistasis as exemplified by the exclusive action of the FGFR2 and MAP3K1 SNPs in $B R C A 2$ mutation carriers (Antoniou et al. 2008).

Acknowledgments We would like to express our gratitude to all the subjects who participated in the study. This work was supported by grants from the Hong Kong Research Grants Council HKU 765008M and HKU 775907M and The University of Hong Kong Seed Funding 200709159003 and 200611159152 to MGB and PT, respectively. Support was also obtained from the University Grants Committee of Hong Kong (AoE/M-04/04) and from The University of Hong Kong Genomics Strategic Research Theme. SSC and PCS are supported by NIH Grant EY-12562. YS is supported by a grant from the Bernoulle Foundation and GB was supported by a NWO grant (no. 901-04-225).

\section{Conflict of interest statement None to declare.}

Open Access This article is distributed under the terms of the Creative Commons Attribution Noncommercial License which permits any noncommercial use, distribution, and reproduction in any medium, provided the original author(s) and source are credited.

\section{References}

Amiel J, Lyonnet S (2001) Hirschsprung disease, associated syndromes, and genetics: a review. J Med Genet 38:729-739

Amiel J, Laudier B, Attie-Bitach T, Trang H, de Pontual L, Gener B, Trochet D, Etchevers H, Ray P, Simonneau M, Vekemans M, Munnich A, Gaultier C, Lyonnet S (2003) Polyalanine expansion and frameshift mutations of the paired-like homeobox gene PHOX2B in congenital central hypoventilation syndrome. Nat Genet 33:459-461

Anderson SL, Coli R, Daly IW, Kichula EA, Rork MJ, Volpi SA, Ekstein J, Rubin BY (2001) Familial dysautonomia is caused by mutations of the IKAP gene. Am J Hum Genet 68:753-758

Angrist M, Bolk S, Halushka M, Lapchak PA, Chakravarti A (1996) Germline mutations in glial cell line-derived neurotrophic factor (GDNF) and RET in a Hirschsprung disease patient. Nat Genet 14:341-344

Antoniou AC, Spurdle AB, Sinilnikova OM, Healey S, Pooley KA, Schmutzler RK, Versmold B, Engel C, Meindl A, Arnold N, Hofmann W, Sutter C, Niederacher D, Deissler H, Caldes T, Kampjarvi K, Nevanlinna H, Simard J, Beesley J, Chen X, Neuhausen SL, Rebbeck TR, Wagner T, Lynch HT, Isaacs C, Weitzel J, Ganz PA, Daly MB, Tomlinson G, Olopade OI, Blum JL, Couch FJ, Peterlongo P, Manoukian S, Barile M, Radice P, Szabo CI, Pereira LH, Greene MH, Rennert G, Lejbkowicz F, Barnett-Griness O, Andrulis IL, Ozcelik H, Gerdes AM, Caligo MA, Laitman Y, Kaufman B, Milgrom R, Friedman E, Domchek SM, Nathanson KL, Osorio A, Llort G, Milne RL, Benitez J, Hamann U, Hogervorst FB, Manders P, Ligtenberg MJ, van den Ouweland AM, Peock S, Cook M, Platte R, Evans DG, Eeles R, Pichert G, Chu C, Eccles D, Davidson R, Douglas F, Godwin AK, Barjhoux L, Mazoyer S, Sobol H, Bourdon V, Eisinger F, Chompret A, Capoulade C, Bressac-de Paillerets B, Lenoir GM, Gauthier-Villars M, Houdayer C, Stoppa-Lyonnet D, Chenevix-
Trench G, Easton DF (2008) Common breast cancer-predisposition alleles are associated with breast cancer risk in BRCA1 and BRCA2 mutation carriers. Am J Hum Genet 82:937-948

Azizi E, Berlowitz I, Vinograd I, Reif R, Mundel G (1984) Congenital megacolon associated with familial dysautonomia. Eur J Pediatr 142:68-69

Badner JA, Sieber WK, Garver KL, Chakravarti A (1990) A genetic study of Hirschsprung disease. Am J Hum Genet 46:568-580

Bar-Shai A, Maayan C, Vromen A, Udassin R, Nissan A, Freund HR, Hanani M (2004) Decreased density of ganglia and neurons in the myenteric plexus of familial dysautonomia patients. J Neurol Sci 220:89-94

Bolk S, Pelet A, Hofstra RM, Angrist M, Salomon R, Croaker D, Buys CH, Lyonnet S, Chakravarti A (2000) A human model for multigenic inheritance: phenotypic expression in Hirschsprung disease requires both the RET gene and a new 9q31 locus. Proc Natl Acad Sci USA 97:268-273

Brooks AS, Bertoli-Avella AM, Burzynski GM, Breedveld GJ, Osinga J, Boven LG, Hurst JA, Mancini GM, Lequin MH, de Coo RF, Matera I, de Graaff E, Meijers C, Willems PJ, Tibboel D, Oostra BA, Hofstra RM (2005) Homozygous nonsense mutations in KIAA1279 are associated with malformations of the central and enteric nervous systems. Am J Hum Genet $77: 120-126$

Brooks AS, Leegwater PA, Burzynski GM, Willems PJ, de Graaf B, van Langen I, Heutink P, Oostra BA, Hofstra RM, Bertoli-Avella AM (2006) A novel susceptibility locus for Hirschsprung's disease maps to 4q31.3-q32.3. J Med Genet 43:e35

Burzynski GM, Nolte IM, Osinga J, Ceccherini I, Twigt B, Maas S, Brooks A, Verheij J, Plaza Menacho I, Buys CH, Hofstra RM (2004) Localizing a putative mutation as the major contributor to the development of sporadic Hirschsprung disease to the RET genomic sequence between the promoter region and exon 2. Eur J Hum Genet 12:604-612

Burzynski GM, Nolte IM, Bronda A, Bos KK, Osinga J, Plaza MI, Twigt B, Maas S, Brooks AS, Verheij JB, Buys CH, Hofstra RM (2005) Identifying candidate Hirschsprung disease-associated RET variants. Am J Hum Genet 76:850-858

Cantrell VA, Owens SE, Chandler RL, Airey DC, Bradley KM, Smith JR, Southard-Smith EM (2004) Interactions between Sox 10 and EdnrB modulate penetrance and severity of aganglionosis in the Sox10Dom mouse model of Hirschsprung disease. Hum Mol Genet 13:2289-2301

Carrasquillo MM, McCallion AS, Puffenberger EG, Kashuk CS, Nouri N, Chakravarti A (2002) Genome-wide association study and mouse model identify interaction between RET and EDNRB pathways in Hirschsprung disease. Nat Genet 32:237-244

Edery P, Lyonnet S, Mulligan LM, Pelet A, Dow E, Abel L, Holder S, Nihoul-Fekete C, Ponder BA, Munnich A (1994) Mutations of the RET proto-oncogene in Hirschsprung's disease. Nature 367:378-380

Fernandez RM, Boru G, Pecina A, Jones K, Lopez-Alonso M, Antinolo G, Borrego S, Eng C (2005) Ancestral RET haplotype associated with Hirschsprung's disease shows linkage disequilibrium breakpoint at -1249. J Med Genet 42:322-327

Fernandez RM, Sanchez-Mejias A, Mena MD, Ruiz-Ferrer M, Lopez-Alonso M, Antinolo G, Borrego S (2009) A novel point variant in NTRK3, R645C, suggests a role of this gene in the pathogenesis of Hirschsprung disease. Ann Hum Genet 73:1925

Fitze G, Cramer J, Ziegler A, Schierz M, Schreiber M, Kuhlisch E, Roesner D, Schackert HK (2002) Association between c135G/A genotype and RET proto-oncogene germline mutations and phenotype of Hirschsprung's disease. Lancet 359:1200-1205

Fitze G, Appelt H, Konig IR, Gorgens H, Stein U, Walther W, Gossen M, Schreiber M, Ziegler A, Roesner D, Schackert HK (2003a) 
Functional haplotypes of the RET proto-oncogene promoter are associated with Hirschsprung disease (HSCR). Hum Mol Genet 12:3207-3214

Fitze G, Cramer J, Serra A, Schreiber M, Roesner D, Schackert HK (2003b) Within-gene interaction between c.135 G/A genotypes and RET proto-oncogene germline mutations in HSCR families. Eur J Pediatr Surg 13:152-157

Gabriel SB, Salomon R, Pelet A, Angrist M, Amiel J, Fornage M, Attie-Bitach T, Olson JM, Hofstra R, Buys C, Steffann J, Munnich A, Lyonnet S, Chakravarti A (2002) Segregation at three loci explains familial and population risk in Hirschsprung disease. Nat Genet 31:89-93

Garcia-Barcelo MM, Sham MH, Lui VC, Chen BL, Song YQ, Lee WS, Yung SK, Romeo G, Tam PK (2003) Chinese patients with sporadic Hirschsprung's disease are predominantly represented by a single RET haplotype. J Med Genet 40:e122

Garcia-Barcelo M, Ganster RW, Lui VC, Leon TY, So MT, Lau AM, Fu M, Sham MH, Knight J, Zannini MS, Sham PC, Tam PK (2005) TTF-1 and RET promoter SNPs: regulation of RET transcription in Hirschsprung's disease. Hum Mol Genet 14:191-204

Garcia-Barcelo MM, Tang CS, Ngan ES, Lui VC, Chen Y, So MT, Leon TY, Miao XP, Shum CK, Liu FQ, Yeung MY, Yuan ZW, Guo WH, Liu L, Sun XB, Huang LM, Tou JF, Song YQ, Chan D, Cheung KM, Wong KK, Cherny SS, Sham PC, Tam PK (2009) Genome-wide association study identifies NRG1 as a susceptibility locus for Hirschsprung's disease. Proc Natl Acad Sci USA 106:2694-2699

Heanue TA, Pachnis V (2006) Expression profiling the developing mammalian enteric nervous system identifies marker and candidate Hirschsprung disease genes. Proc Natl Acad Sci USA 103:6919-6924

Hofstra RM, Osinga J, Tan-Sindhunata G, Wu Y, Kamsteeg EJ, Stulp RP, van Ravenswaaij-Arts C, Majoor-Krakauer D, Angrist M, Chakravarti A, Meijers C, Buys CH (1996) A homozygous mutation in the endothelin-3 gene associated with a combined Waardenburg type 2 and Hirschsprung phenotype (Shah-Waardenburg syndrome). Nat Genet 12:445-447

Hofstra RM, Valdenaire O, Arch E, Osinga J, Kroes H, Loffler BM, Hamosh A, Meijers C, Buys CH (1999) A loss-of-function mutation in the endothelin-converting enzyme 1 (ECE-1) associated with Hirschsprung disease, cardiac defects, and autonomic dysfunction. Am J Hum Genet 64:304-308

Hofstra RM, Wu Y, Stulp RP, Elfferich P, Osinga J, Maas SM, Siderius L, Brooks AS, vd Ende JJ, Heydendael VM, Severijnen RS, Bax KM, Meijers C, Buys CH (2000) RET and GDNF gene scanning in Hirschsprung patients using two dual denaturing gel systems. Hum Mutat 15:418-429

Kiba T, Kintaka Y, Suzuki Y, Nakata E, Ishigaki Y, Inoue S (2009) Ventromedial hypothalamic lesions change the expression of neuron-related genes and immune-related genes in rat liver. Neurosci Lett 455:14-16

Lang D, Epstein JA (2003) Sox10 and Pax3 physically interact to mediate activation of a conserved c-RET enhancer. Hum Mol Genet 12:937-945

Lang D, Chen F, Milewski R, Li J, Lu MM, Epstein JA (2000) Pax3 is required for enteric ganglia formation and functions with Sox 10 to modulate expression of c-ret. J Clin Invest 106:963-971

McCallion AS, Stames E, Conlon RA, Chakravarti A (2003) Phenotype variation in two-locus mouse models of Hirschsprung disease: tissue-specific interaction between Ret and Ednrb. Proc Natl Acad Sci USA 100:1826-1831

Mezey E, Parmalee A, Szalayova I, Gill SP, Cuajungco MP, Leyne M, Slaugenhaupt SA, Brownstein MJ (2003) Of splice and men: what does the distribution of IKAP mRNA in the rat tell us about the pathogenesis of familial dysautonomia? Brain Res 983:209214

Park B, Nguyen NT, Dutt P, Merdek KD, Bashar M, Sterpetti P, Tosolini A, Testa JR, Toksoz D (2002) Association of Lbc Rho guanine nucleotide exchange factor with alpha-catenin-related protein, alpha-catulin/CTNNAL1, supports serum response factor activation. J Biol Chem 277:45361-45370

Pingault V, Bondurand N, Kuhlbrodt K, Goerich DE, Prehu MO, Puliti A, Herbarth B, Hermans-Borgmeyer I, Legius E, Matthijs G, Amiel J, Lyonnet S, Ceccherini I, Romeo G, Smith JC, Read AP, Wegner M, Goossens M (1998) SOX10 mutations in patients with Waardenburg-Hirschsprung disease. Nat Genet 18:171-173

Price AL, Patterson NJ, Plenge RM, Weinblatt ME, Shadick NA, Reich D (2006) Principal components analysis corrects for stratification in genome-wide association studies. Nat Genet 38:904-909

Puffenberger EG, Hosoda K, Washington SS, Nakao K, deWit D, Yanagisawa M, Chakravart A (1994) A missense mutation of the endothelin-B receptor gene in multigenic Hirschsprung's disease. Cell 79:1257-1266

Purcell S, Neale B, Todd-Brown K, Thomas L, Ferreira MA, Bender D, Maller J, Sklar P, de Bakker PI, Daly MJ, Sham PC (2007) PLINK: a tool set for whole-genome association and populationbased linkage analyses. Am J Hum Genet 81:559-575

Romeo G, Ronchetto P, Luo Y, Barone V, Seri M, Ceccherini I, Pasini B, Bocciardi R, Lerone M, Kaariainen H et al (1994) Point mutations affecting the tyrosine kinase domain of the RET protooncogene in Hirschsprung's disease. Nature 367:377-378

Sancandi M, Griseri P, Pesce B, Patrone G, Puppo F, Lerone M, Martucciello G, Romeo G, Ravazzolo R, Devoto M, Ceccherini I (2003) Single nucleotide polymorphic alleles in the 5' region of the RET proto-oncogene define a risk haplotype in Hirschsprung's disease. J Med Genet 40:714-718

Sklar P, Smoller JW, Fan J, Ferreira MA, Perlis RH, Chambert K, Nimgaonkar VL, McQueen MB, Faraone SV, Kirby A, de Bakker PI, Ogdie MN, Thase ME, Sachs GS, Todd-Brown K, Gabriel SB, Sougnez C, Gates C, Blumenstiel B, Defelice M, Ardlie KG, Franklin J, Muir WJ, McGhee KA, MacIntyre DJ, McLean A, VanBeck M, McQuillin A, Bass NJ, Robinson M, Lawrence J, Anjorin A, Curtis D, Scolnick EM, Daly MJ, Blackwood DH, Gurling HM, Purcell SM (2008) Whole-genome association study of bipolar disorder. Mol Psychiatry 13:558569

Slaugenhaupt SA, Gusella JF (2002) Familial dysautonomia. Curr Opin Genet Dev 12:307-311

Slaugenhaupt SA, Blumenfeld A, Gill SP, Leyne M, Mull J, Cuajungco MP, Liebert CB, Chadwick B, Idelson M, Reznik L, Robbins C, Makalowska I, Brownstein M, Krappmann D, Scheidereit C, Maayan C, Axelrod FB, Gusella JF (2001) Tissuespecific expression of a splicing mutation in the IKBKAP gene causes familial dysautonomia. Am J Hum Genet 68:598-605

Sunyaev S, Ramensky V, Koch I, Lathe W III, Kondrashov AS, Bork P (2001) Prediction of deleterious human alleles. Hum Mol Genet 10:591-597

Torfs CP (1998) An epidemiological study of Hirschsprung disease in a multiracial California population. In: The third international meeting: Hirschsprung disease and related neurocristopathies, Evian, France, 1998

Wakamatsu N, Yamada Y, Yamada K, Ono T, Nomura N, Taniguchi H, Kitoh H, Mutoh N, Yamanaka T, Mushiake K, Kato K, Sonta S, Nagaya M (2001) Mutations in SIP1, encoding Smad interacting protein-1, cause a form of Hirschsprung disease. Nat Genet 27:369-370 